\title{
REAKSI PAS TERHADAP LAPORAN SURUHANJAYA REID DAN ISLAM SEBAGAI AGAMA PERSEKUTUAN DALAM PEMBENTUKAN PERLEMBAGAAN MERDEKA
}

\author{
Abdul Halim bin Ramli \\ Mohammad Redzuan Othman \\ Ahmad Kamal Ariffin bin Mohd Rus
}

\begin{abstract}
The formation of the Reid Commission in 1956 was a pivotal point for the formulation of the Federation of Malaya Constitution that led the country's independence on August 31, 1957. After recording the vieus of various parties and ethnic groups in Malaya, the Reid Commission wrote its report. However, after the Reid Conmission Report 7oas issued on February 21, 1957, PAS, the Malay opposition party, strongly criticized the report. This article discusses the criticism of PAS on the report and examines the policies of the party before and at the beginning of independence. In accordance with the policy of PAS to make Malaya as a Muslinn country and a Malay nation, the party strongly criticized the status of lslam as proposed in the Reid Report and as stated in the Federal Constitution of 1957. This resistance continued after independence until the rise of disputes between PAS and UMNO due to differences in the interpretation of I slam and the weaknesses in the inplenentation of Islam in the country.
\end{abstract}

\section{Pengenalan}

Perbicangan mengenai reaksi dan kritikan PAS terhadap Laporan Suruhanjaya Reid bertujuan untuk memahami faktor-faktor penolakan PAS terhadap Laporan Reid yang dianggap merugikan orang Melayu. 
Perbezaan pandangan PAS mengenai isu yang berkaitan dengan kedudukan agama Islam, kedudukan bahasa Melayu, kedudukan istimewa orang Melayu dan hak kerakyatan kaum bukan Melayu dengan pandangan parti UMNO-Perikatan menjadi asas penentangan dan pertembungan antara PAS dengan UMNO-Perikatan bukan sahaja sebelum merdeka tetapi lebih hebat selepas merdeka. Reaksi dan kritikan PAS bukan sahaja lantang semasa proses pembentukan Perlembagaan Persekutuan 1957 dilakukan tetapi berterusan selepas kemerdekaan negara, terutama yang menyangkut dengan kedudukan Islam dan isu yang berkaitan dengan isu orang Melayu.

Terdapat beberapa reaksi dan kritikan PAS terhadap kedudukan Islam sebagai agama bagi Persekutuan terutama selepas merdeka iaitu dari tahun 1957 hingga 1964. Perbezaaan interpretasi mengenai kedudukan Islam dalam Perlembagaan di antara PAS dan UMNO ini adalah faktor utama wujudnya pertembungan yang sengit di antara dua parti orang Melayu tersebut. Pertembungan tersebut telah memberi kesan yang besar kepada perpaduan orang Melayu dan banyak mempengaruhi iklim politik Malaysia pasca merdeka.

\section{Penubuhan Parti Islam SeMalaysia}

Perbincangan mengenai sejarah penubuhan PAS selalunya dimulakan dengan membincangkan penubuhan Hizbul Muslimin (HAMIM) pada 14 Mac 1948 di Maahad al-Syarif, Gunung Semanggol Perak oleh Abu Bakar al-Baqir. Dasar perjuangan Hizbul Muslimin adalah berasaskan Islam yang bertujuan untuk mencapai "kemerdekaan bangsa Melayu yang berdaulat, mencipta masyarakat yang berlandaskan Islam dan mencapai Tanah Melayu Darul Islam (negara Islam)". Walau bagaimanapun, penubuhan Hizbul Muslimin tidak disenangi oleh Inggeris dan UMNO (ditubuhkan pada 1946). Pada bulan Ogos 1948, kerajaan Inggeris telah menggunakan Undang-undang Darurat 1948 bagi menangkap tujuh orang pemimpin Hizbul Muslimin, termasuk ketuanya, Abu Bakar al-Baqir.' Pengharaman Hizbul Muslimin telah membawa kepada penubuhan PAS pada bulan Ogos 1951. Penubuhan PAS adalah hasil inisiatif beberapa bek as aktivis Hizbul Muslimin yang terlibat secara langsung membantu Tuan Haji Ahmad Fuad bin Hassan (bekas Pengerusi Badan Agama UMNO) menubuhkan sebuah parti politik Islam.' Nama PAS asalnya ialah Persatuan Ulamak SeMalaya kemudian ditukar kepada Persatuan Islam SeMalaya seterusnya ditukar kepada Persatuan Islam SeTanah Melayu setelah Tanah Melayu mencapai kemerdekaan pada 1957. Bagaimanpun, apabila Malaysia ditubuhkan pada tahun 1963, sekali lagi PAS telah ditukar nama sebagai Parti Islam SeMalaysia. ${ }^{3}$ 
Pada tahap awal penubuhannya, PAS telah dipimpin oleh Tuan Haji Ahmad Fuad. Menurut Funston, pada masa awal penubuhannya, PAS hanya sebuah parti yang wujud pada namanya saja. Pada penghujung tahun 1952, PAS hanya mempunyai keahlian tidak melebihi 5000 orang ahli, kebanyakannya di sekitar Gunung Semanggol, Perak. Walau bagaimanapun, mulai tahun 1953, PAS telah disusun semula. Perlembagaan parti PAS telah dipinda dalam Mesyuarat Agung PAS pada Ogos 1954 untuk menjadikan perjuangan utamanya adalah untuk mencapai kemerdekaan dan memperjuangkan perlaksanaan Islam dalam masyarakat dan negara. ${ }^{4}$

Titik perubahan penting yang telah menjadikan PAS sebuah parti Islam yang berpengaruh berlaku setelah beberapa pemimpin awalnya meninggalkan PAS seperti $\mathrm{Hj}$. Ahmad Fuad yang menyertai Independence Malayan Party (IMP) pimpinan Dato' Onn Jaafar dan kemasukan beberapa orang tokoh baru yang karismatik ke dalam PAS seperti Mohamad Asri Muda, Dr. Buhanuddin al-Helmy dan Zulkifli Muhammad. ${ }^{5}$ Misalnya, Dr. Burhanuddin al-Helmy telah memasuki PAS pada 14 Disember 1956 dan menjadi Yang Dipertua Agong PAS pada 25 Disember 1956. Kemasukan beliau ke dalam PAS telah memberi kesan yang besar kepada perjuangan PAS menjadi sebuah parti yang progresif dan tersusun. Di bawah kepimpinanya, PAS menjadi sebuah parti Islam yang mempunyai ciri Islam, nasionalis dan anti penjajah. ${ }^{6} \mathrm{Di}$ bawah kepimpinan beliau juga, PAS telah memainkan peranan penting memperjuangkan hak-hak orang Melayu supaya tidak dipinggirkan, terutama semasa Suruhanjaya Reid menjalankan tugasnya bagi membentuk Perlembagaan Persekutuan Tanah Melayu Merdeka pada tahun 1956 dan 1957.

\section{Pembentukan Suruhanjaya Reid}

Perlembagaan Persekutuan Tanah Melayu 1957 dibentuk melalui evolusi sejarah kompromi antara kaum yang sudah bermula dari tahun 1955 seperti yang dinyatakan oleh S. Falle, Ramlah Adam ${ }^{8}$ dan J.M. Fernando. Pembentukan Perlembagaan Persekutuan Tanah Melayu bermula pada tahun 1956 ekoran pertemuan kerajaan Perikatan yang dipimpin oleh Tunku Abdul Rahman dengan Lennox-Boyd, Setiausaha Tanah Jajahan British di Kuala Lumpur pada 22 Ogos 1955. Pertemuan ini kemudiannya telah membawa kepada perbincangan yang lebih serius mengenai kemerdekaan Tanah Melayu antara delegasi Kuala Lumpur dengan kerajaan British di London pada 18 Januari hingga 6 Februari 1956. ${ }^{10}$ Konfrensi London membawa hasil yang sangat bermakna kerana ia tidak sekadar bahawa British telah bersetuju memberikan Tanah Melayu sebagai full self-Government tetapi turut menubuhkan sebuah 
suruhanjaya bebas seperti y ang diminta oleh kerajaan Perikatan dalam janji mereka pada pilihan raya pertama Persekutuan Tanah Melayu 1955. Pembentukan suruhanjaya bebas tersebut adalah untuk membentuk sebuah Perlembagaan Persekutuan Tanah Melayu yang merdeka yang dipersetujui oleh semua kaum. Pada bulan Mac 1956, Suruhanjaya bebas tersebut telah dibentuk dan dikenali sebagai Suruhanjaya Reid."

Ahli yang dilantik untuk menganggotai Suruhanjaya Reid telah dipersetujui oleh Majlis Raja-raja dan Menteri Perikatan. Suruhanjaya Perlembagaan tersebut terdiri daripada sebuah badan yang kecil, di mana Pengerusi dan satu daripada ahlinya dipilih oleh United Kingdom, manakala ahli yang lain masing-masing satu dipilih oleh Kanada, Australia, India dan Pakistan. ${ }^{12}$ United Kingdom telah memilih Lord Reid ${ }^{13}$ dan Sir Ivor Jennings, ${ }^{14}$ manakala kerajaan Australia telah memilih Sir William McKell, ${ }^{15}$ India memilih Hakim B. Malik dan Hakim Hanid ${ }^{16}$ dipilih oleh kerajaan Pakistan. Suruhanjaya ini dilantik atas nama $\mathrm{Her}$ Majesty The Queen dan Raja-raja Melayu. Terma rujukan Suruhanjaya ini dalam menjalankan tugas mereka ialah "untuk memeriksa aturan perlembagaan yang wujud di seluruh Tanah Melayu, mengambil kira kedudukan dan martabat Ratu Inggeris dan Raja Melayu" dan "untuk memberikan cadangan terhad ap perlembagaan berbentuk persekutuan untuk seluruh negara sebagai unit tunggal, bebas dan berkerajaan sendiri dalam lingkungan Komanwel berdasarkan demokrasi berparlimen dengan dua dewan perundangan yang turut merangkumj peruntukan:(1) Penubuhan kerajaan pusat yang kuat dengan negeri dan tanah jajahan mempunyai sejumlah kebebasan, (2) Memelihara kedudukan dan martabat Raja sebagai Raja Berperlembagaan di negeri masing-masing, (3) Seorang Yang di-Pertuan Besar (Yang diPertuan Agong) untuk Persekutuan akan dipilih daripada Raja, (4) Kewarganegaraan yang sama untuk seluruh Persekutuan dan (5) Menjaga kedudukan istimewa masyarakat Melayu dan kepentingan masyarakat yang sah. ${ }^{1 ?}$

Pengerusi Suruhanjaya, iaitu Lord Reid telah memulakan tugas mereka dengan melawat Malaya pada bulan Mei 1956, dan diikuti dengan kedatangan ahlinya yang lain pada bulan Jun. Suruhanjaya ini telah menjemput rakyat di negara ini menghantar pandangan mereka terhadap isu yang berkaitan dengan perlembagaan. Pihak Suruhanjaya Reid telah menerima 131 memorandum dari orang perseorangan dan organisasi yang mewakili semua komuniti dan kepentingan semua rakyat di negara ini. ${ }^{18}$ Walau bagaimanapun, golongan yang banyak pandangan dan memorandum tersebut adalah kaum bukan Melayu. PAS turut menghantar memorandum kepada Suruhanjaya Reid. Namun, memorandum yang menjadi rujukan dan asas dalam penyediaan Laporan Reid adalah memorandum Perikatan. Keadaan ini 
berlaku disebabkan memorandum Perikatan lebih menyuarakan hasrat pelbagai kaum, manakala memorandum PAS hanya mewakili kelompok orang Melayu sahaja. ${ }^{19}$ Semasa proses penghantaran memorandum kepada Suruhanjaya Reid, PAS dilihat kurang lantang bersuara berbanding pihak lain, namun setelah Laporan Reid dikeluarkan, PAS mula memainkan peranan lebih aktif berbanding sebelu mnya. ${ }^{20}$

\section{Reaksi dan Kritikan PAS Terhadap Laporan Reid}

Laporan Reid yang dikeluarkan pada 21 Februari 1957 telah menimbulkan pelbagai reaksi daripada orang Melayu, kaum bukan Melayu, parti-parti politik, media dan berbagai pertubuhan, terutamanya mengenai isu-isu yang ada hubung kaitnya dengan isu komunal. Akhbar Utusan Melayn, telah mempersoalkan kewajaran Suruhanjaya yang memasukkan semakan terhadap hak istimewa orang Melayu setelah tempoh 15 tahun. Akhbar Cina, Kwong Wah Jit Poh bertarikh 21 Februari 1957, telah mengkritik Suruhanjaya kerana mewujudkan dua darjat kerakyatan dengan merujuk kepada hak istimewa orang Melay u dalam Perlembagaan. ${ }^{21}$

Manakala PAS (Parti Islam Se Malaya) pada 17 Mac 1957, telah mengadakan satu rapat umum di Padang Malaya, Kuala Terengganu yang dihadiri kira-kira 2,000 orang penyokong membantah Laporan Reid. Dalam rapat umum tersebut, Dr. Burhanuddin al-Helmy (Yang Dipertua Agung PAS) telah menyatakan bahawa syor-syor dalam Suruhanjaya Reid tersebut merugikan bangsa Melayu dan terbabas daripada keadilan. Nama bangsa Melayu telah terhapus dan jaminan kedaulatan bangsa Melayu dan agama Islam telah ditinggalkan. ${ }^{22}$ Rapat umum yang dihadiri oleh pemimpin Parti Negara, Parti Rakyat dan PAS bersama dengan orang Melayu juga telah diadakan di Padang Kelab Sultan Sulaiman, Kuala Lumpur pada 10 Mac 1957, dan diikuti rapat umum di padang Muar Club pada 16 Mac 1957. Dalam rapat umum di Padang Muar Club, Dato' Onn telah berucap (ucapannya disiarkan dalam akhbar Kritik pada 20 Mac 1957) yang menzahirkan kebimbangannya dan kebimbangan bangsa Melayu berkenaan implikasi Laporan Reid terhadap nasib masa depan bangsa Melayu. Dato' Onn menegaskan bahawa matlaniat rapat umum yang diadakan bertujuan untuk "umat bangsa Melayu berkehendak tahu apakah akan jadinya kepada negeri-negeri Melayu dan umat bangsa Melayu di Semenanjung Tanah Melayu ini... khasnya selepas 31 hari bulan Ogos hadapan ini".

PAS dalam reaksinya terhadap Laporan Reid pula telah mengeluarkan satu ulasan terhadap Laporan Reid. Ulasan tersebut (mengandungi 23 muka surat) telah dibentangkan dan dibahaskan dalam Sidang Mesyuarat Agung Khas PAS pada 2 Mei 1957, di Kuala 
Lumpur. Ulasan tersebut memperlihatkan kekecewaan PAS terhadap cadangan Suruhanjaya yang dilihatnya sebagai berlawanan dengan "tertib kedudukan politik negara ini dan hendak meruntuhkan pewujudan sebuah negara merdeka". PAS berpendirian bahawa negara ini adalah sebuah negara Melayu dan hak orang Melayu telah diakui dan diiktiraf oleh sejarah dan undang-undang. Oleh kerana itu, hak politik negara ini adalah terpulang semata-mata kepada orang Melayu yang mempunyai hak mutlak dan tuan punya kepada negara ini. Dalam Laporan tersebut, PAS menolak kaedah jus soli yang digunakan dalam soal kerakyatan, kerana ia akan merugikan orang Melayu. Tuntutan bukan Melayu terhadap penggunaan syarat kerakyatan yang longgar pada pandangan PAS didorong oleh tujuan untuk merebut kuasa politik dan membantut perkembangan politik di negara ini. Bantahan PAS terhadap prinsip jus soli bertujuan "bukan semata-mata kerana hendak merasakan kepentingan orang Melayu sahaja, tetapi merenungkan kepada keselamatan dan kebajikan negeri ini, apabila mencapai kemerdekaannya kelak...". ${ }^{23}$

Bantahan PAS terhadap syarat-syarat kerakyatan yang longgar, di mana hak kerakyatan boleh diberikan kepada sesiapa sahaja yang lahir dalam negara ini diasaskan kepada kebimbangan PAS terhadap kesetiaan orang bukan Melayu terhadap negara inj dan dalam masa yang sama, mereka masih belum melucutkan hak kebangsaannya dari negara asal mereka. Oleh kerana itu menurut PAS, "ini bermaknalah kerakyatan Persekutuan Tanah Melayu ini boleh dipermainkan oleh barang siapa pun dari rakyat lain..."..$^{24}$

PAS juga mengkritik Laporan Suruhanjaya Reid kerana tidak menegaskan bahawa kebangsaan Persekutuan Tanah Melayu dinamakan sebagai Kebangsaan Melayu. Bagi PAS; "tujuan tertentu di dalam tugas Suruhanjaya itu, ialah bagi mewujudkan satu kebangsaan umum di negeri ini, maka hendaklah disebut bahawa hendaklah diwujudkan satu kebangsaan di Tanah Melayu ini, dan kebangsaan itu hendaklah dinamakan MELAYU" ${ }^{25}$

Ulasan PAS terhadap Laporan Suruhanjaya Reid itu juga menegaskan bahawa salah satu tugas penting Laporan Reid adalah untuk menjaga "kedudukan khas bangsa Melayu dan kepentingan halal bagi puak yang lain". Penjagaan hak kedudukan istimewa orang Melayu berdasarkan kepada hakikat bahawa Tanah Melayu adalah kepunyaan bangsa Melayu. Sebarang percubaan untuk mengubah hakikat ini dilihat oleh PAS sebagai berlawanan dengan hak manusia dan asas undang-undang. PAS menyatakan kekecewaannya terhadap Laporan Reid kerana "...mereka itu mementingkan kedudukan khas bangsa lain di Tanah Melayu..." dan sedikit tumpuan yang diberikan kepada bangsa Melayu yang disifatkan oleh PAS; "bukan sebagai 
bangsa yang mempunyai hak dan mempunyai negeri Tanah Melayu ini, tetapi sebagai sa-gulongan manusia yang kechil, yang lemah, yang patut di-berikan pertolongan, yang sama kedudukan-nya dengan kaum Eurasian, dan sama-lah seperti puak-puak yang lemah di-negeri ini. Ini adalah satu pengkhianatan yang besar yang telah di-lakukan oleh Surohanjaya itu" ${ }^{\prime 26}$

Dalam Laporan Suruhanjaya Reid, hak istimewa orang Melayu dicadangkan untuk disemak kembali selepas 15 tahun merdeka. Perkara tersebut dinyatakan dalam Laporan Reid "We recommend that after 15 years there should be a review of the whole matter and that the procedure should be that appropriate Government should cause a report to be made and laid before the appropriate legislature...". ${ }^{27}$ Batasan waktu mengenai hak istimewa orang Melayu seperti yang diputuskan oleh Suruhanjaya Reid sebenarnya tidak terdapat dalam memorandum Perikatan yang diserahkan kepada Suruhanjaya $\operatorname{Reid}^{28}$ kerana ia tidak menyatakan apa-apa syarat mengenai hak istimewa orang Melayu . $^{29}$ Walau bagaimanapun, batasan masa hak keistimewaan orang Melayu telah ditimbulkan pada 27 September 1956 oleh Tun Abdul Razak ketika sesi perbincangan bersama ahli Surthanjaya Reid mengenai memorandum yang dihantar oleh Perikatan kepada Suruhanjaya Reid. Batasan masa dan penyempitan skop hak istimewa orang Melayu seperti yang diputuskan oleh Suruhanjay a Reid telah menimbulkan bantahan daripada orang Melayu termasuk dari ahli UMNO sendiri. Bagi mereka, sekiranya cadangan Suruhanjaya Reid itu diterima keseluruhannya maka perkara tersebut akan mendatangkan bencana yang besar ke atas nasib orang Melayu. ${ }^{30}$

Penentangan yang kuat terhadap Laporan Suruhanjaya Reid datang dari parti-parti pembangkang Melayu seperti PAS dan Parti Negara. Dalam memorandum yang dihantar kepada Suruhanjaya Reid, PAS telah menegaskan bahawa memelihara kedudukan istimewa bangsa Melayu merupakan tanggungjawab asas yang perlu dilakukan oleh Suruhanjaya Reid kerana Tanah Melayu adalah kepunyaan bangsa Melayu. Sebarang percubaan untuk mengubah status ini adalah berlawanan dengan hak manusia dan asas undang-undang. Suruhanjaya Reid wajib membuat takrifan yang tepat mengenai kedudukan bangsa Melayu sebagai bangsa yang mempunyai hak di dalam negeri ini. Namun apabila Laporan Reid dikeluarkan, PAS merasa terkejut dan kecewa terhadap Suruhanjaya Reid kerana gagal melaksanakan tugas mereka sebagai menjaga kepentingan bangsa Melayu. Sebaliknya mereka mementingkan kedudukan khas bangsa lain pula. ${ }^{31}$

PAS melihat Laporan Reid sebagai satu pengkhianatan yang besar kepada bangsa Melayu kerana melupakan hakikat sejarah negeri ini yang dipunyai oleh bangsa Melayu. PAS membantah pembatasan takrif 
hak istimewa orang Melayu seperti yang disebut dalam perenggan $165,^{32} 166^{33}$ dan $167^{34}$ Laporan Reid. Menurut perenggan-perenggan tersebut, hak istimewa orang Melayu yang diakui ialah berkenaan kuota atau rizab Melayu (Malay resere) untuk orang Melayu memasuki perkhidmatan awam, permit atau lesen, biasiswa dan lain-lain bantuan untuk pelajaran..$^{35}$ Takrif hak keistimewaan orang Melayu ini bagi PAS adalah "satu kebodohan yang kita tidak mengerti". Selanjutnya PAS menyebutkan:

Orang Melayu punya negeri ini, maka yang hendak di-beri oleh Surohanjaya itu ia-lah Malay reserve, supaya di-hadkan-lah orang Melayu di-dalam Malay reserve itu sahaja, dan yang hendak di-beri supaya di-hadkan orang Melayu masuk di-dalam public service (perkhidmatan am) dan licence2 yang hendak di-berikan kepada orang Melayu pun hendak di-hadkan sekira2 dapat-lah di-pura2kan memberi bantuan kepada orang Melayu. Surohanjaya ini tidak menyembut apa yang patut di-sebut-nya, ia-itu bahawa kedudukan khas orang Melayu di-Tanah Melayu ini hendak-lah di-akui berkenaan dengan bahawa negeri ini ada-lah di-punyai oleh orang Melayu, ini tidak di-sebut-nya; bahkan di-sebut-nya perkara2 yang kecil seperti tadi. ${ }^{36}$

Manakala pandangan PAS mengenai kedudukan Islam sebagai agama bagi Persekutuan hendaklah ditafsirkan Islam sebagai satu cara hidup yang menyeluruh bukan semata-mata ibadah antara hamba dengan Tuhannya sahaja. ${ }^{37}$ 'Tujuan agama Islam yang dituntut oleh PAS dijadikan sebagai agama bagi Persekutuan supaya:

Agama Islam lah menjadi PEMANDU, dan menjadi TUJUAN didalam hidop manusia dinegeri ini. Maka dengan menyebutkan ini didalam Perlembagaan Persekutuan Tanah Melayu yang merdeka akan menjadi sabuah negeri yang benar-benar berfaedah bagi dirinya sendiri, dan akan menimbulkan hasil baik pada rakyatnya, dalam arti kata KESELAMATAN, KESEJAHTERAAN, dan KEMAKMURAN". is

Lanjutan tuntutan Islam sebagai agama bagi Persekutuan, PAS menuntut supaya Perdana Menteri yang dilantik mestilah dari seorang yang beragama Islam. ${ }^{39}$

Cadangan-cadangan yang telah dikemukakan oleh Suruhanjaya Reid mengenai kedudukan bahasa Melayu juga telah ditolak oleh PAS. PAS dalam ulasannya mengenai isu bahasa telah mencadangkan supaya Suruhanjaya Reid menjadikan bahasa Melayu sebagai bahasa rasmi dan bahasa Kebangsaan yang tunggal dengan serta merta, tanpa menunggu tempoh tertentu. Dengan adanya peruntukan seperti itu maka bahasa lain selain daripada bahasa Melayu tidak akan ada kesempatan dan ruang untuk dijadikan sebagai bahasa rasmi di Tanah Melayu. PAS juga 
menolak cadangan multi-lingralism dalam Dewan Undangan. Sekiranya dasar ini diterima, maka ia akan membuka ruang kepada bahasa lain untuk diangkat sebagai bahasa rasmi. Lanjutan dari menjadikan bahasa Melayu sebagai bahasa rasmi, maka hak untuk mendapatkan kerakyatan mestilah mengetahui bahasa Melayu dengan baik. PAS juga membantah penggunaan bahasa Inggeris sebagai bahasa rasmi dalam tempoh 10 tahun selepas merdeka kerana bagi PAS sebagai "hendak membina sesuatu, dan dalam membina itu meruntuhkannya sendiri". Justeru itu, PAS menuntut supaya penegasan dibuat dalam Suruhanjaya Reid bahawa "bahasa rasmi Tanah Melayu dan bahasa Kebangsaan Tanah Melayu yang TUNGGAL ialah BAHASA MELAYU“.40

\section{Kritikan PAS Terhadap Draf Perlembagaan Merdeka}

Laporan Reid yang menyediakan cadangan draf Perlembagaan Persekutuan Tanah Melayu telah diserahkan untuk dinilai oleh Badan Kerja (Working Party) yang mengandungi empat orang wakil dari Raja-raja Melayu, empat orang wakil dari kerajaan yang dikuasai oleh Perikatan, Pesuruhjaya Tinggi British, Ketua Setiausaha dan Peguam Negara yang mewakili kerajaan British. Badan Kerja ini dipengerusikan oleh MacGillivray (Pesuruhjaya Tinggi British). Badan ini telah membuat semakan terhadap draf tersebut dari bulan Mac hingga April 1957. ${ }^{41}$ Walau bagaimanapun, sebagai badan penilai, mereka tidak boleh mengubah struktur umum draf perlembagaan yang diasaskan kepada Perlembagaan Persekutuan Tanah Melayu 1948. Tugas utama Badan Kerja tersebut ialah untuk memastikan bahawa perlembagaan baru yang digubal bersesuaian dengan bentuk pemerintahan di Malaya. ${ }^{42}$ Dengan sebab itu, Badan Kerja telah mengadakan sebanyak 23 kali mesyuarat dalam tempoh antara 22 Februari hingga 27 April 1957 sebelum sesuatu keputusan yang muktamad diambil bagi membentuk draf Perlembagaan yang diterima oleh semua pihak. ${ }^{43}$

Ringkasnya, perbincangan dan perbahasan dalam Badan Kerja telah membawa kepada beberapa perubahan terhadap beberapa peruntukan yang mempunyai hubungan dengan isu-isu komunal seperti yang terdapat dalam draf Perlembagaan Suruhanjaya Reid. Perubahan tersebut berkaitan dengan peruntukan mengenai kedudukan agama Islam sebagai agama rasmi, hak istimewa orang Melayu tanpa sempadan masa dan penolakan cadangan Suruhanjaya mengenai penggunaan bahasa Tamil dan Mandarin dalam Dewan Undangan Persekutuan (Federal Legislatif Council) untuk tempoh 10 tahun. Bagi mewujudkan keseimbangan dalam tuntutan wakil MCA dan MIC dalam Badan Kerja, UMNO telah berkompromi dengan memberikan perlindungan dalam perlembagaan penggunaan dan pengajaran bahasa 
Tamil atau Mandarin dalam urusan awam atau bukan rasmi. Di samping itu, UMNO telah menggugurkan cadangannya untuk mewajibkan calon pilihan raya yang bertanding mesti mempunyai keupayaan bertutur dalam bahasa Melay u atau Inggeris. ${ }^{44}$

Perbincangan akhir Badan Kerja telah diadakan di London pada 13 hingga 21 Mei 1957 (dikenali sebagai Konferensi London). Tujuan konferensi London diadakan adalah untuk mencapai persetujuan mengenai masa depan Perlembagaan Persekutuan Tanah Melayu dan menyelesaikan beberapa perkara bagi memudahkan draftsmen menyediakan intrumen perlembagaan baru Tanah Melayu. Perbincangan di London telah dihadiri oleh kerajaan Tanah Melayu yang diketuai oleh Tunku Abdul Rahman, wakil Raja-raja Melayu dan kerajaan British yang diketuai oleh Setiausaha Tanah Jajahan British. ${ }^{+5}$

Laporan mengenai hasil Konferensi tersebut menyebut bahawa segala permasalahan yang menjadi isu (seperti soal dua kerakyatan) yang dibangkitkan semasa Suruhanjaya Reid menyediakan laporan mereka telah dapat diselesaikan. Persetujuan telah dapat dicapai bagi menyediakan sebuah Perlembagaan baru yang akan dikuat kuasakan pada 31 Ogos 1957 setelah Tanah Melayu mencapai kemerdekaan. ${ }^{46}$ Konferensi London lebih banyak tertumpu kepada isu perubahan teknikal terhadap draf Perlembagaan supaya lebih sempurna dari sudut undang-undang. ${ }^{47}$ Perbincangan di London telah meluluskan draf Perlembagaan yang disediakan oleh Suruhanjaya dengan beberapa perubahan yang penting dibuat oleh Working Party ${ }^{48}$ tanpa mengubah kerangka asasnya. ${ }^{49}$

Konfrensi London telah menerbitkan Kertas Putih yang dikenali sebagai Constitutional Proposals for the Federation of Malaya. Melalui Kertas Putih ini telah dibuat beberapa pindaan terhadap Laporan Suruhanjaya Reid dan diterima dengan sebulat suara melalui Perhimpunan Agung UMNO pada 30 Jun 1957. Setelah berlakunya perbahasan selama sebelas jam oleh 125 orang perwakilan yang dijalankan secara tertutup, ia juga turut diterima oleh UMNO. ${ }^{50}$ Walau bagaimanapun, PAS pula telah mengkritik Kertas Putih tersebut kerana ia menghapuskan negerinegeri Melayu, menghapuskan ketuanan Melayu, di samping PAS beranggapan bahawa Pulau Pinang dan Melaka masih menjadi hak baginda Queen, cuma hak pemerintahan saja yang diserahkan kepada rakyat kedua-dua negeri tersebut. ${ }^{51}$ Menteri besarnya tidak disyaratkan dengan ketentuan Melayu dan/atau beragama Islam. Prinsip jus soli telah diterima, syarat kerakyatan longgar dan Perlembagaan tidak boleh dipinda lagi sehingga diadakan pilihan raya pada tahun 1959 dengan persetujuan dua pertiga ahli Dewan Undangan Persekutuan. ${ }^{52}$ Justeru itu, kemerdekaan yang dicapai pada 31 Ogos 1957 diibaratkan PAS sebagai "menang sorak, kampung tergadai". Corak dan nilai 
perlembagaan Kertas Putih yang telah diterima itu "ibarat nasi telah menjadi bubur", kerana ia merupakan syor yang terkandung dalam Laporan Reid telah menghalang matlamat perjuangan PAS untuk membentuk sebuah negara yang berasaskan kepada kebangsaan Melayu yang berpaksikan kepada satu bahasa, satu negara dan satu bangsa. ${ }^{53}$

\section{Reaksi PAS Mengenai Pelaksanaan Kedudukan Islam Dalam Perlembagaan}

Berasaskan kepada latar belakang sejarah bahawa Islam telah pun menjadi agama rasmi bagi negeri-negeri Melayu (sebelum pembentukan Perlembagaan Persekutuan Tanah Melayu 1957) serta persetujuan yang telah dicapai oleh semua pihak, terutama parti Perikatan telah berjaya meletakkan Islam sebagai agama bagi Persekutuan Tanah Melayu (Perkara 3(1) Perlembagaan Persekutuan 1957). Sebenarnya sebelum Memorandum Perikatan disiapkan dan dihantar kepada pihak Suruhanjaya Reid pada 27 September 1956, kedudukan agama Islam dinyatakan sebagai "agama bagi Malaysia hendaklah agama Islam", rencana Pengarang majalah Pengasuh keluaran bulan Februari 1956 telah menyeru kepada rakyat yang beragama Islam di negara ini supaya bersatu dalam satu suara yang bulat mendesak Duli-duli Yang Maha Mulia Raja-raja Melayu dan wakil-wakil Melayu dalam Dewan Undangan Persekutuan supaya menjadikan kedudukan agama Islam pada masa akan datang sebagai agama rasmi Persekutuan, bukan sekadar agama rasmi di negeri-negeri Melayu semata-mata. Tuntutan tersebut menurut Pengarang majalah Pengasuh ialah "memang menjadi hak kita yang asasi. Kita sudah cukup bertoleransi berlapang dada dalam segi kebangsaan, tetapi segi ini kita terpaksa berdiri teguh, kerana inilah saja benteng kita yang akhir untuk mengawal keutamaan dan keagungan bangsa kita". ${ }^{54}$

Kejayaan meletakkan Islam sebagai agama bagi Persekutuan seperti yang dicadangkan oleh UMNO-Perikatan melalui Memorandumnya yang dihantar dan dijadikan asas dalam Laporan Suruhanjaya Reid dan dipersetujui sebulat suara di Dewan Undangan Persekutuan pada Julai 1957 telah disambut dengan perasaan gembira oleh orang Islam. Mereka memahami bahawa peruntukan tersebut hanya meliputi perkara-perkara yang biasa dijalankan pada zaman penjajahan Inggeris dahulu dan tidak mengimplikasikan pelaksanaan hukumhukum Islam secara menyeluruh. ${ }^{55}$ Walau bagaimanapun, PAS yang tujuan penubuhannya memperjuangkan sebuah masyarakat dan pemerintahan di negara ini yang melaksanakan nilai-nilai hidup dan hukum-hukum Islam ${ }^{50}$ secara konsisten sama ada sebelum dan selepas merdeka mengkritik kelemahan peruntukan tersebut (Islam 
sebagai agama rasmi), di samping bertindak menolak Perlembagaan Persekutuan kerana bercanggah dengan al-Quran dan Sunah. Melalui majalah Suara Islam yang diterbitkan pada tahun 1957 dan menjadi wadah penyaluran idealisme PAS, PAS menyifatkan "kata-kata Islam agama rasmi" dalam Perlembagaan adalah huruf-huruf yang kaku dan mati yang tidak mempunyai daya dan tenaga apa-apa yang boleh mengembalikan kedaulatan Islam di negara ini. Peruntukan tersebut hanya kulit bukannya isi, manakala Islam masih terjajah walaupun negara telah mencapai kemerdekaan. Peruntukan tersebut hanya lebih bererti kalau segala aspek perundangan di negara ini berdasarkan alQuran dan Sunnah. ${ }^{57}$

Kemerdekaan penuh bagi PAS ialah "melainkan berjalan hukum Islam pada orang seorang, masyarakat dan negara". Pendirian PAS ialah "bahawa tiap-tiap hukum yang tidak sesuai dengan al-Quran dan Sunah adalah batal dan tidak sah. Maka termasuklah Perlembagaan yang tidak sesuai dengan al-Quran dan Sunnah adalah batal pada pandangan dan pendirian Islam". Justeru itu, pengakuan Islam sebagai agama rasmi adalah tidak terpakai pada sisi hukum Islam, kalau sekadar "hanya dituliskan sahaja Islam sebagai agama rasmi, kecuali bolehlah dipakai apakala aturan-aturan dan hukum-hukum serta undangundang asasi didirikan oleh kerajaan itu dibina di atas undang-undang Islam...".5 Manakala hukum atau undang-undang yang dijalankan merupakan lanjutan dari hukum-hukum jahiliah, hukum yang berasal dari Rom, Parsi atau Greek serta dikeluarkan oleh golongan manusia yang meyakinkan mereka berasal daripada monyet..$^{5 i}$ Pendirian tersebut diulangi oleh PAS pada tahun 1958, kali ini PAS menyifatkan Perlembagaan Persekutuan Tanah Melayu tidak sesuai dengan jiwa orang Melayu dan tidak menurut ayidah serta semangat keislaman." Matlamat perjuangan PAS adalah untuk membebaskan umat Islam di negara ini daripada belenggu sistem jahilliyah yang menguasai masyarakat dan negara. PAS mahu membebaskan masyarakat daripada belenggu sistem jahilliyah yang terus menerus dipertahankan oleh UMNO. Matlamat PAS adalah untuk menegakkan sebuah negara Islam dan ketiadaan negara Islam adalah "mungkar yang besar".

Walaupun terdapat gesaan daripada sebahagian orang Melayu dan umat Islam yang inginkan Islam itu dilaksanakan dalam semua aspek penghidupan sesuai dengan kedudukan dan taraf Islam seperti yang dimaktubkan dalam perlembagaan, namun Tunku Abdul Rahman sering kali mengulangi pendiriannya bahawa Malaysia tidak akan menjadi sebuah negara Islam dan kekal dengan statusnya sebagai sebuah negara sekular. Pendirian tersebut diucapkannya di Dewan Undangan Persekutuan pada tahun 1958, "I would like to make it clear that this country is not an lslamic State as it is generally understood, we merely 
prozide that Islam shall be the official religion of the state" ${ }^{62}$ Pendirian yang sama diulanginya pada tahun 1959 yang dipetik dalam akhbar New Straits Time, bertarikh 1 Mei 1959. Di samping itu, Dr. Ismail bin Dato' Abdul Rahman (Menteri Luar Negeri) semasa membahaskan usul memberhentikan Loteri Kebajikan Masyarakat yang dibuat oleh PAS di Dewan Rakyat pada 14 Disember 1959 turut menegaskan perkara yang sama. Menurut Dr. Ismail:

Jadi supaya hendak menarik perhatian kita, diingatkan semula apa yang telah berlaku dalam Pilihan Raya (1959). Sebagai parti Perikatan kita berkata iaitu jika kita diangkat menjadi kerajaan, kita sanggup menjadikan agama Islam agama rasmi dan pentadbiran bukanlah mengikut cara Islam. Dan bagi PAS pula kalau menjadi kerajaan, dia bukan sahaja menjadikan agama Islam agama rasmi bahkan akan menjalankan pentadbiran dengan cara Islam. Parti Perikatan telah menang, jadi mengikut demokrasi pentadbiran negeri ini berjalalah dengan tidak secara Islam, tetapi Islam menjadi agama rasmi negeri ini... ${ }^{63}$

Tunku turut menegaskan bahawa agama tidak boleh dicampuradukkan dengan politik, kalau agama dicampuradukkan dengan politik maka akan mendatangkan bahaya kepada Tanah Melayu. Tunku membidas PAS yang menggunakan agama sebagai "canouflage their dirty game" ${ }^{54}$ Sementara itu, Tun Abdul Razak pula menyifatkan tindakan PAS menggunakan agama sebagai satu dosa dan akan memecah belahkan orang Melayu ${ }^{65}$ Tunku melihat tindakan tersebut amat membahaya, kerana agama Islam telah menjadi tunggak orang Melayu pada masa lampau ketika mereka dijajah oleh bangsa asing. ${ }^{66}$

Tuntutan dan perjuangan PAS yang berterusan untuk menjadikan Tanah Melayu sebagai sebuah negara Islam menyebabkan Tunku Abdul Rahman mencabar PAS supaya menunjukkan sebuah negara di dunia ini yang mengamalkan pemerintahan Islam seperti yang dikehendaki oleh PAS. Tunku menyelar PAS dengan membuat beberapa kesimpulan antaranya, amalan hukum-hukum Islam tidak dapat dilaksanakan di dunia, kecuali 100 peratus rakyatnya terdiri daripada orang-orang Islam dan sekiranya hukum-hukum Islam dilaksanakan maka huru hara akan berlaku. Kenyataan Tunku ini kemudiannya telah diulas oleh Pengarang majalah Qalam dengan menyatakan bahawa menegakkan sebuah negara Islam adalah wajib bagi setiap umat Islam. Majalah Qalam mengingatkan Tunku su paya berhati-hati mengeluarkan tuduhan kepada parti lawan kerana "terkadang-kadang telah menyentuh perasaan orang-orang yang beragama seperti apa yang disebutkan di atas, kerana umat Islam mengerti dan yakin bahawa kalau hukum Allah dijalankan di negara ini akan aman, berbahagia dan makmur serta diberkati Tuhan". ${ }^{67}$ 
Islam yang menjadi asas perjuangan PAS, terutama untuk mewujudkan sebuah negara Islam dan faham kebangsaan Melayu yang penuh $^{68}$ sentiasa ditegaskan oleh Dr. Burhanuddin al-Helmy dalam ucapan-ucapannya. Matlamat tersebut telah menjadi ikrar dan iltizam PAS dalam perjuangannya selepas merdeka serta menjadi senjata utama PAS bagi menarik sokongan rakyat terutama orang Melayu yang berada di luar bandar dan negeri-negeri di pantai timur yang kuat dengan pengaruh golongan agama. Isunya seperti, untuk menjadikan agama Islam sebagai agama rasmi negara, semakan semula terhadap Perlembagaan 1956 bagi memulangkan semula kedaulatan orang Melayu sebagai peribumi, menjadikan bahasa Melayu sebagai bahasa pengantar sekolah kebangsaan dan menentukan hanya orang Melayu sahaja yang boleh menjadi Menteri Besar telah dijadikan Manifesto PAS dalam pilihan raya $1959 .(1)$

PAS sebagai sebuah parti pembangkang Melayu/Islam berterusan mendesak kerajaan Perikatan supaya lebih tegas melaksanakan amalan Islam selaras dengan kedudukan yang diberi dalam Perlembagaan. Misalnya, pada bulan Disember 1963, semasa membahaskan "The Suplly Bill 1963", Dr. Burhanuddin al-Helmy telah mendesak kerajaan Perikatan melaksanakan tiga perkara penting. Pertama, beliau mendesak kerajaan supaya mengambil langkah-langkah yang tegas bagi mengiktiraf agama Islam sebagai agama rasmi Persekutuan. Beliau tidak mahu penyataan itu hanya sekadar di atas kertas sahaja. Kedua, sistem perundangan negara ini menggunakan hukum-hukum Islam yang berdasarkan al-Quran dan Sunah sebagai semangat dan jiwa pentadbiran negeri ini. Ketiga, kerajaan perlu menyusun semula sistem pendidikan agama dan para gurunya wajar menerima gaji yang lebih baik. ${ }^{70}$ Persoalan guru agama yang dibayar dengan gaji yang rendah telah dibangkitkan oleh Abdul Karim bin Abu (Ahli Dewan Rakyat dari Melaka Selatan) di Dewan Rakyat pada 26 Mei 1965. Menurut beliau, walaupun Islam telah dijadikan agama rasmi di negara ini tetapi yang menyedihkan guru agama hanya dibayar gaji sekitar $\$ 80$ atau $\$ 90$ sebulan. Keadaan ini membawa makna bahawa kerajaan seolah-olah merendahkan pengakuan atau nilaian pelajaran agama lslam yang diagungkan menjadi agama rasmi di negara ini."

Dalam pilihan raya 1964, PAS telah menjadikan isu mewujudkan sebuah negara Islam dalam Perlembagaan negara sebagai isu utama dalam kempen politik mereka dalam pilihan raya tersebut. PAS berjanji akan melaksanakan prinsip-prinsip Islam sekiranya mereka mendapat kuasa dalam pilihan raya tersebut. Dalam kempen PAS, UMNO terus dituduh mengkhianati Islam bukan sahaja kerana UMNO telah mengorbankan nilai-nilai rohaniah untuk kemajuan kebendaan, tetapi kerana kerjasamanya dengan MCA dan MIC dalam Perikatan. PAS 
telah berkempen dari rumah ke rumah untuk memberi amaran kepada pengundi Melayu bahawa mereka akan melanggar ajaran Islam (kafir) sekiranya mereka mengundi calon bukan Islam atau mengundi UMNO yang menjalinkan hubungan kerjasama yang erat dengan bukan Islam (Parti Perikatan). ${ }^{72}$ PAS telah menjadikan nas-nas al-Quran sebagai alasan untuk menentang perikatan antara UMNO-MCA-MIC. Ayatayat al-Quran daripada Surah ali-Imran (28) dan lain-lain surah telah dijadikan rujukan bagi membuktikan betapa Allah melarang penganut Islam berikat dengan orang-orang bukan Islam atau menjadikan mereka sebagai pemimpin. ${ }^{73}$

Untuk menunjukkan sejauh mana UMNO telah mengabaikan islam, PAS mendakwa kerajaan Perikatan bertanggungjawab membenarkan kaum Cina memelihara babi berhampiran dengan rumah orang Melayu ${ }^{74}$ Dalam usaha UMNO untuk mengimbangi perjuangan PAS, UMNO berhujah bahawa mereka juga turut menyumbang kepada pembangunan Islam, misalnya, kerajaan Perikatan telah membelanjakan sejumlah wang yang besar untuk mendirikan masjid dan surau di seluruh negara. Manakala PAS yang mendakwa dirinya sebagai penjaga Islam, tidak melakukan perkara tersebut, hatta di Kelantan sendiri yang dikuasai oleh PAS. ${ }^{75}$ UMNO mendakwa bahawa mereka telah meletakkan agama dalam semua aspek pembangunan negara. Misalnya dalam aspek pelajaran, pelajaran agama Islam telah diajarkan di semua sekolah rendah, menengah, pengajian tinggi dan menubuhkan Kolej Islam yang merupakan sebuah pusat pengajian tinggi agama di negara ini. ${ }^{76}$ Bagaimanapun PAS masih melihat dasar pembangunan negara yang dilaksanakan oleh UMNO sebagai satu pembangunan yang mungkar. Ini disebabkan pembangunan tersebut masih berasaskan sistem kapitalis dan sosialis. Menurut PAS, pembangunan yang tidak berasaskan panduan Allah adalah pembangunan yang meruntuhkan. ${ }^{77}$

Setiap kali PAS mengkritik kelemahan UMNO dalam memperkukuhkan kedudukan orang Melayu dalam aspek ekonomi, bahasa, pendidikan termasuk agama Islam maka UMNO bertindak menjawab kembali tuduhan tersebut dengan mendedahkan kelemahan pemerintahan PAS di negeri yang dikuasainya seperti di Kelantan (PAS menguasai Kelantan semenjak pilihan raya 1959). Umpamanya, penolakan dan kritikan keras PAS terhadap Akta Bahasa Kebangsaan 1967 yang dibahaskan di Dewan Rakyat pada 3 Mac 1967 telah membawa Tun Abdul Razak (Timbalan Perdana Menteri ketika itu) mendedahkan kelemahan kerajaan PAS di Kelantan. Menurut Tun Razak:

Di negeri Kelantan saya kata tadi 7-8 tahun PAS memerintah satu apa kemajuan tidak dapat dijalankan. PAS yang mengagong-agongkan agama Islam sebuah masjid pun tidak didirikan. UMNO, Perikatan, 
telah dirikan beribu-ribu masjid di bandar dan di kampung. Masjid yang ada di ibu kota Negeri PAS, di Kota Baharu, masjid sudah buruk. Orang-orang Islam di Kota Baharu terpaksa sembahyang di tepi tangga di atas rumput. Inilah keadaan negeri yang diperintah oleh PAS...Ada kuasa tidak boleh menjalankan satu apa. Negeri PAS sekarang ini papa. Kalau saya tidak beri pertolongan, kerajaan PAS Kelantan tidak dapat membayar gaji pegawai-pegawai kerajaan. ${ }^{78}$

Menurut Tun Razak, pembangunan Kelantan di bawah pemerintahan PAS telah tercicir 10 tahum berbanding negeri-negeri lain. Kerajaan Perikatan telah membelanjakan kira-kira \$1.6 juta untuk membina masjid, surau dan sekolah agama di Kelantan pada tahun 1968. ${ }^{79}$ Tindakan yang dilakukan oleh kerajaan tersebut selaras dengan kedudukan Islam sebagai agama rasmi negara.

Tunku Abdul Rahman dalam ucapan perasmiannya dalam Perhimpunan Agung UMNO pada 14 hingga 15 Oktober 1967 juga mengambil peluang dalam perhimpunan tersebut untuk mengutuk PAS yang menyebarkan dakyah bahawa orang Melayu selepas merdeka berada dalam kerugian. Tunku mengibaratkan dakwaan tersebut sebagai "iblis dan syaitan yang hendak mengabui mata dan menutup pintu hati manusia yang boleh membawa manusia kepada jalan yang sesat dan merosakkan fikiran yang sihat. Tunku sama seperti Tun Razak mengkritik kelemahan kerajaan PAS Kelantan yang tidak banyak membantu orang Melayu. Kemunduran Kelantan menurut Tunku telah menyebabkan orang Kelantan berhijrah ke merata-rata negeri yang berada di bawah pemerintahan Perikatan untuk mendapatkan tanah, menumpang hidup dan mengecap nikmat kebahagiaan yang tidak mereka dapati di negeri mereka sendiri di bawah pemerintahan PAS. Tunku turut menempelak PAS, kerana tindakan PAS menyebelahi Sukarno dan Subandrio untuk menceroboh Malaysia pada zaman konfrantasi Malaysia-Indonesia (1964). ${ }^{8}$ PAS berjanji kepada rakyat Kelantan jika mereka menang dalam pilihan raya umum, mereka akan memberi kemudahan kepada rakyat dari segi ekonomi dan meninggikan ajaran Islam. PAS juga berikrar untuk menjadikan Kelantan sebagai bahdatul taibatun warabulghafur. Walau bagaimanapun janji tersebut tidak dapat dilaksanakan kerana melihat realiti pembangunan dan perlaksanaan ajaran Islam tidak banyak berubah di Kelantan. ${ }^{81}$

Kritikan yang berterusan PAS terhadap UMNO kerana kegagalannya melaksanakan ajaran Islam secara menyeluruh di dalam urusan negara menyebabkan UMNO terpaksa merangka strategi bagi memulihkan persepsi orang Melayu terhadap UMNO sebagai sebuah parti politik yang turut mendaulatkan ajaran Islam. Dalam makalah yang bertajuk "Tugas Kita Terhadap Negara" yang terdapat 
dalam buku "Gerakan Tahan Lasak" Pemuda UMNO yang menjadi panduan bagi Pemuda UMNO menghadapi Pilihan raya 1969, UMNO menyedari bahawa parti tersebut akan hilang keperibadiannya jika mereka meninggalkan agama dan membelakangkan atau meninggalkan orang yang berpengaruh dalam agama. ${ }^{82}$ Justeru itu, UMNO mesti meyakinkan orang Melayu bahawa UMNO adalah sebuah parti yang berjuang untuk agama. Perjuangan mereka untuk memartabatkan agama adalah sama dengan perjuangannya dalam bidang-bidang lain seperti yang terkandung dalam Perlembagaan UMNO. UMNO berkewajiban "melayani kehendak-kehendak agama dan ajaran agama mestilah sama besarnya dengan kepentingan-kepentingan nasional dan tidak mungkin dilakukan berat sebelah" ${ }^{83}$ UMNO perlu menarik orang agama berjuang dalam UMNO. Perbuatan yang menjauhkan orang beragama daripada UMNO mestilah ditinggalkan, supaya UMNO tidak dicop sebagai parti yang mempermain-mainkan agama. ${ }^{84}$

Isu-isu berhubung hak orang Melayu dan kedudukan agama Islam telah dimainkan oleh PAS dan Parti Negara dalam pilihan raya 1959 yang menyaksikan negeri-negeri yang majoriti Melayu seperti Kelantan dan Terengganu jatuh ke tangan penguasaan PAS dan kemenangan Dato' Onn (Parti Negara) di Terengganu. Paridah Ali telah menyimpulkan beberapa faktor utama kemenangan PAS tersebut seperti kelemahan jentera UMNO setempat, krisis dalaman Perikatan (Julai 1959), kesilapan UMNO yang terlalu yakin dan tidak melihat kepentingan rakyat setelah berjaya dalam pilihan raya 1955 . Selain itu, cita-cita politik Islam telah diterima oleh rakyat Kelantan dan Terengganu serta ideologi yang diperjuangkan PAS mempunyai kesesuaian dengan jiwa masyarakat negeri tersebut yang mempunyai pegangan agama yang teguh. ${ }^{85}$ Justeru itu, PAS yang menjadikan Islam sebagai dasar perjuangannya dengan bercita-cita untuk menubuhkan sebuah negara Islam dilihat sebagai umpan yang sangat menarik bagi menarik perhatian orang Melayu untuk menyokongnya. ${ }^{86}$

PAS juga telah menggunakan pengaruh tokoh-tokoh setempat bagi mendapatkan kepercayaan pengundi seperti pengaruh sekolah-sekolah pondok dan alim ulamak tempatan bagi mendorong rakyat memilih calon PAS. ${ }^{87}$ Tunku Abdul Rahman telah menuduh PAS menggunakan agama bagi mendapatkan sokongan orang Melayu kerana orang Melayu keseluruhannya berpegang kuat dengan agama tersebut. PAS menurut Tunku tidak mempunyai pengetahuan untuk mengubal satu dasar ekonomi yang membangun sebagaimana yang patut dibuat oleh sebuah parti politik. ${ }^{88}$ Dalam ucapannya di Padang Muar dan Parit Medan, Johor pada bulan Mac 1959, Tunku telah mengecam PAS kerana menggunakan agama demi kepentingan politiknya dan menuduh PAS bersimpati dengan komunisme. Menurut Tunku lagi, PAS mahukan 
supaya undang-undang darurat ditarik balik. PAS juga dikatakan telah menghantar wakil mereka ke Konferensi Pemuda Afro-Asian yang diadakan di Kaherah pada tahun 1959 sedangkan Rusia adalah dalang di sebalik penganjuran konferensi tersebut. ${ }^{89}$

Selain itu, tindakan PAS yang menganjurkan supaya Singapura bercantum dengan Tanah Melayu dijadikan hujah oleh Tunku yang mendakwa PAS sebagai Pro-Komunis. Ini disebabkan di Singapura terdapat bilangan anggota komunis yang ramai sehingga boleh menghancurkan Tanah Melayu. Pada masa yang sama, PAS juga telah mendakwa Tunku menentang perjanjian pertahanan antara Tanah Melayu dengan Britain di mana tujuan utama perjanjian tersebut adalah untuk menjamin keselamatan Tanah Melayu daripada ancaman komunis. PAS juga telah melantik Khatijah binti Sidek sebagai Ketua Wanitanya sedangkan Khatijah merupakan bekas tahanan (dipenjara dua tahun di Singapura). ${ }^{\circ}$

Konflik yang berterusan antara UMNO dengan PAS akibat daripada perbezaan dasar perjuangan mereka dan keghairahan kedua-dua parti politik meraih sokongan daripada orang Melayu serta ingin memaparkan perjuangan mereka adalah lebih Islamik telah menyebabkan timbulnya isu kafir-mengkafir. Isu ini mula timbul, terutama menjelang pilihan raya Persekutuan 1959. UMNO telah menud uh PAS mengkafirkannya, namun tud uhan itu telah ditolak oleh Dr. Buhanuddin al-Helmy. Menurut Dr. Burhanuddin al-Helmy, dasar perjuangan PAS bukanlah kafir mengkafirkan sesiapa. Tujuan PAS adalah "memperjuangkan cita-cita Islam dan hendak membela kembali hak ketuanan Melayu kerana itulah dikatakan hak dan keadilan yang sebenarnya"." Walaupun isu mengkafirkan UMNO tidak dilakukan oleh para pemimpin utama PAS seperti Dr. Burhanuddin al-Helmy, Zulkefli Muhammad dan Mohamed Asri Muda, namun terdapat juga golongan ulamak daripada PAS dituduh mengeluarkan fatwa mengkafirkan UMNO. Misalnya pada tahun 1963, tok guru terkenal dari Pasir Mas, Haji Omar Daud dituduh mengeluarkan fatwa mengkafirkan UMNO."

Isu kafir mengkafir ini kemudiannya berterusan dalam pilihan raya 1964 dan 1969. Tindakan tersebut didakwa telah digunakan oleh PAS untuk melemahkan sokongan rakyat kepada UMNO dalam pilihan raya tersebut. Justeru itu, tindakan tersebut lebih bertujuan politik untuk melemahkan sokongan orang Melayu terhadap UMNO terutama di negeri Pantai Timur di mana pengaruh PAS lebih dominan. Dengan sebab itu, isu kafir mengkafir ini lebih ketara timbul apabila sesuatu pilihan raya umum diadakan. PAS telah menggunakan kelemahan UMNO melaksanakan Islam secara menyeluruh dan kerjasamanya dengan parti politik non-muslim sebagai alasan untuk menuduh UMNO 
sebagai sebuah parti politik yang tidak Islamik. Walaupun sebenarnya PAS tidak menyebutkan UMNO secara langsung dalam fatwa yang dikeluarkan oleh Dewan Ulamaknya. Misalnya, pada bulan Ogos 1963, satu mesyuarat telah diadakan di kediaman Menteri Besar Kelantan, Dewan Ulamak PAS telah membuat keputusan mengeluarkan fatwa, "...orang-orang Islam yang berkongsi dengan orang-orang kafir untuk memerintah negara menjadi kafir atau haram", "sesiapa yang mengundi di atas parti-parti yang berkongsi itu menjadi haram, jika redha menjadi kafir, tetapi jika tidak menjadi haram sahaja...". Berikutan dengan fatwa tersebut, seorang ahli Dewan Ulamak PAS, iaitu Haji Yaakob bin Ishak telah menyatakan bahawa orang Perikatan adalah "kafir" dengan alasan berikut,

1) "apabila keputusan ini diambil saya berpendapat bahawa seseorang umat Islam yang memasuki parti yang berkongsi dengan orang-orang kafir, jikalau redha menjadi kafir. Orang-orang Islam menjadi ahli Perikatan jikalau redha menjadi kafirlah mereka...".

2) "sekiranya seorang ahli Perikatan menyembelih lembu atau binatang lain, ahli-ahli PAS tidak boleh makannya kerana ahli-ahli Perikatan kafir".93

Fatwa tersebut diakui oleh Haji Abu Bakar Abdul Rahman (seorang pendakwah PAS Kelantan) telah dikeluarkan oleh PAS. Menurut beliau "apa yang difatwakan oleh Dewan Ulamak PAS itu adalah menurut hukum yang sebenar dan fatwa itu telah disahkan oleh mufti Kelantan sendiri" ${ }^{94}$ Fatwa yang dikeluarkan oleh PAS menyebabkan Tunku Abdul Rahman mengeluarkan amaran akan bertindak tegas terhadap golongan yang menyebarkan fatwa tersebut. Amaran Tunku telah menimbulkan reaksi keras daripada pemimpin dan ulamak PAS Kelantan. Umpamanya, Haji Abu Bakar Abdul Rahman mensifatkan cabaran Tunku tersebut sebagai menentang hukum Allah dan berlawanan dengan ajaran Islam. Nik Abdullah $\mathrm{Hj}$. Arshad (ahli Dewan Undanagan Kelantan) pula mencabar golongan yang menentang fatwa Dewan Ulamak PAS yang mengkafirkan penyokong-penyokong Perikatan supaya membakar al-Qur'an. Sementara Ketua Pemuda PAS Kelantan, En. Abdul Samad pula menuduh Tunku seorang yang suka menentang ajaran Islam dan mencabar Tunku menangkap dirinya sendiri sebelum menangkap ulamak-ulamak PAS. ${ }^{95}$

Isu kafir mengkafir kesan daripada fatwa yang dikeluarkan oleh Dewan Ulamak PAS telah menyebabkan Jawatankuasa Tetap Agama Bagi Majlis Raja-raja Melayu mengadakan mesyuarat pada 27 dan 28 Mei 1963 bagi membincangkan isu tersebut. Jawatankuasa tersebut 
telah mengeluarkan fatwa melarang kafir mengkafir sesama umat Islam. Keputusan mesyuarat jawatankuasa mengulas bahawa:

...dengan sebulat suara ahli-ahli jawatankuasa berpendapat adalah kafir mengkafirkan seorang Islam itu satu daripada perkara yang dipandang tersangat berat dalam agama Islam, kiranya orang yang dihadapkan kepadanya perkataan itu tidak tepat sifat-sifat yang menjadikan dia murtad, maka kembalilah hukum murtad itu kepada orang yang berkata itu pula...oleh itu inilah ahli-ahli Jawatankuasa Tetap Agama Bagi Majlis Raja-raja mendatangkan nasihat kepada sekalian ikhwan muslimin iaitu kalimah kafir mengkafirkan seseorang Islam itu hendaklah dipelihara lidah masing-masing daripadanya, sama ada dalam kempen-kempen atau perbualan hari-hari atau lainya. ${ }^{96}$

Terdapat desakan supaya Tunku bertindak menangkap golongan tersebut, terutama sebelum pilihan raya 1964 berlangsung. ${ }^{97}$ Fatwa mengkafirkan tersebut telah menyebabkan 10 orang yang terlibat ditahan di bawah Akta Keselamatan Dalam Negeri termasuk Haji Omar bin Daud (ahli Dewan Ulamak PAS dan ahli Dewan Negeri Bandar Pasir Mas) pada tahun 1963 dan 1964. Isu kafir mengkafir ini menjadi reda apabila PAS berjaya mengekalkan kuasa di Kelantan dan Terengganu dalam pilihan raya 1964 dan 1969. Isu ini terhenti selepas Peristiwa 13 Mei 1969, setelah pembentukan kerajaan campuran PAS-Perikatan pada tahun $1973 .{ }^{98}$

\section{Kesimpulan}

Secara kesimpulannya ternyata PAS memang merupakan penentang kuat terhadap Laporan Suruhanjaya Reid. Ini kerana laporan tersebut merupakan satu pengkhianatan yang besar dan merugikan orang Melayu terutama cadangannya untuk mengkaji semula kedudukan istimewa orang Melayu selepas 15 tahun merdeka, menjadikan bahasa Melayu sebagai bahasa kebangsaan dan rasmi tunggal hanya selepas 10 tahun merdeka, penggunaan prinsip jus soli dalam memberi hak kerakyatan kepada kaum bukan Melayu, penolakan terhadap kebangsaan Melayu dan interprestasi yang rigid Islam sebagai agama bagi Persekutuan. Laporan Reid dan Kertas Putih yang diterbitkan hasil dari Konferensi London secara jelas mentafsirkan kedudukan Islam sebagai agama bagi Persekutuan tidak membawa pengertian bahawa negara ini bukan sebuah Negara Keduniaan atau Secular State, tidak menghalang kebebasan beragama di negara ini dan tidak menggugat kedudukan Raja-raja Melayu sebagai Ketua Agama bagi negeri masingmasing 
Persetujuan lisan yang dicapai antara pemimpin parti Perikatan mengenai kedudukan Islam dalam Perlembagaan cuba dipertahankan oleh Tunku Abdul Rahman pada zaman pemerintahannya. Justeru itu, beliau sering mengulangi pendiriannya bahawa Tanah Melayu (ketika itu) tidak akan menjadi sebuah negara Islam dan kekal statusnya sebagai sebuah negara sekular. Padahal perkataan sekular atau kenyataan yang menunjukkan bahawa negara ini adalah sebuah negara sekular tidak wujud secara bertulis dalam Perlembagaan Persekutuan 1957. Bagaimanapun, PAS sebagai sebuah parti politik yang memperjuangkan pembentukan sebuah negara Islam telah menolak kedudukan Islam yang diberikan oleh Perlembagaan (berasaskan Laporan Reid) kerana kedudukan tersebut tidak membawa kepada perlaksanaan Islam secara menyeluruh, terutama dalam soal undang-undang. Perbezaan pandangan ini telah membawa konflik dan pertembungan yang sengit di antara PAS dan UMNO sehingga menimbulkan ketegangan hubungan sesama Melayu dan antara faktor yang melatarbelakangi timbulnya isu takfir bermula semenjak tahun 1959.

Konflik kedua-dua parti yang didukung oleh orang Melayu ini berpunca daripada perbezaan pendekatan dan matlamat politik namun menjalar kepada persoalan aqidah. Kelemahan UMNO melaksanakan kehendak Perkara 3 iaitu Islam sebagai agama bagi Persekutuan, telah digunakan oleh PAS untuk menarik sokongan orang Melayu kepadanya dan berjaya menguasai Kelantan dan Terengganu, terutama dalam pilihan raya 1959 . Untuk melemahkan pengaruh PAS yang semakin meningkat, UMNO bertindak menuduh PAS sebagai parti yang dipengaruhi Komunis dan menggunakan agama demi kepentingan politik mereka. Bagaimanapun tuduhan tersebut tidak berupaya melemahkan pengaruh PAS, bahkan sokongan orang Melayu terhadap parti tersebut tidak banyak berubah dalam pilihan raya 1969 (memenangi 12 kerusi Parlimen). Kemenangan tersebut disebabkan PAS menggunakan kelemahan UMNO dalam melaksanakan Islam dan memperjuangkan hak-hak orang Melayu sebagai isu sehingga parti tersebut dianggap sebagai sebuah parti radikal Melayu. Ringkasnya, isu agama yang dibangkitkan oleh PAS dan UMNO telah berperanan meningkatkan ketegangan kaum, terutama dalam konteks hubungan sesama Melayu. PAS berjaya melemahkan pengaruh UMNO di kalangan orang Melayu. Ini dapat dibuktikan di kawasan pilihan raya yang didominasi oleh kaum Melayu (lebih 90 peratus pengundi Melayu), calon PAS lebih berjaya disebabkan isu-isu Melayu yang dimainkan oleh PAS dalam pilihan raya tersebut. Kesan daripada perkembangan tersebut, menyebabkan UMNO dan Perikatan semakin hilang kawalan ke atas kerajaan dalam pilihan raya 1969. 


\section{Nota}

1 Lihat Suara Islam Kearah Menegak Daulah Islamiah, Bil. 7, April, 1981, hlm. 8. Lihat juga Funston, Malay Politics in Malaysia, Kuala Lumpur: Heinemann Asia, 1980, hlm. 91.

2 Lihat Ishak Saat, Sejarah Politik Melayn Pelbagai Aliran, Shah Alam: Karisma Publications Sdn. Bhd., 2007, hlm. 228-233

3 Lihat AGP/4/B, Parti Islam SeMalaysia, "Riwayat Penubuhan PAS dan Dewan Ulamak", Kuala Lumpur: Jabatan Penerangan PAS Pusat, 1991.

4 N.J. Funston, Malay Politics in Malaysia: A Study of UMNO \& PAS, hlm. 94-95.

$5 \quad$ Ibid., hlm. 95

- Ismail Said, Dr. Burhanuddin al-Helni Perjuang Melayu Sejati, Shah Alam: Karisma Publication Sdn. Bhd., 2008, hlm. 41.

FCO 24/251(32), British High Commission to Secretary of State For Commonwealth Affairs, 6 April 1967.

8 Ramlah Adam, Biografi Politik Tunku Abdul Rahnan Putra, Kuala Lumpur: Dewan Bahasa dan Pustaka, 2004.

$9 \quad J$ Joseph M. Fernando, The Making of the Malayan Constitutiont, The Malaysian Branch of the Royal Asiatic Society, 2002.

10 Lihat $\mathrm{CO} 1030 / 257$, Report of the Federation of Malay Constitutional Conference Held in London, January and February, 1956.

11 Lihat Federation of Malay Constitution Commission, 1956-1957, hlm. 1.

12 DO 35/6275, Lihat Constitutional Commission on the Federation of Malaya, 1956. DO 35/6275

13 Lord Reid dilahirkan pada tahun 1890 dan mempunyai pengalaman yang luas sebagai pegumbela dan hakim. Beliau juga pernah menjadi ahli parlimen untuk beberapa tahun. Beliau pernah menjadi Salitor-General bagi negara Scotland dari tahun 1930 hingga 1941. Beliau menjadi Lord Adeocate dari tahun 1941 hingga 1945 dan Dekan Fakulti Undang-undang dari tahun 1945 hingga 1948. Semenjak tahun 1948, beliau dilantik sebagai Lord of Appeal, CO 1030/136, Federation of Malaya Constitutional Commission Membership, 1956.

14 Beliau dilahirkan pada tahun 1903. Beliau pernah menjadi ahli Suruhanjaya Pendidikan di Malaya pada tahun 1947. Pada tahun 1948 dilantik sebagai ahli Suruhanjaya Perlembagaan Ceylon. Dari tahun 1954 hingga 1955 dilantik sebagai penasihat Perlembagaan dan ketua Draftsman bagi Perlembagaan Pakistan. Beliau juga dilantik sebagai Pengerusi Suruhanjaya Diraja undang-undang Tanah Common Law. Ibid.

15. Beliau pernah bertugas sebagai Governor-Genarl Australia dari tahun 1947 hingga 1953. Pernah menjawat pelbagai jawatan seperti Menteri Keadilan dan Penolong Treasurer dari tahun 1925 hingga 1927, Menteri Kerajaan Tempatan 1930-1931. Ibid

16. Dilahirkan pada tahun 1903. Mendapat pendidikan di Ediards Mission College di Peshawar dan University Punjab dan Lohore. Pernah menjawat jawatan sebagai Secretary Legislative Assembly di N.W.F.P pada tahun 1932 hingga 1938. Menjadi hakim kanan pada tahun 1938-1947. Pernah 
bekhidmat di Kementerian Undang-undang dan dilantik sebagai Hakim Mahkamah Tinggi pada tahun 1955. Ibid.

17 DO 35/6275, Extract From Official Report, Report of Columns 45-46, 14 Mac 1956.

18 Federation of Malay Constitutional Commission, 1956-1957, hlm. 3. Menurut Laporan Suruhanjaya Reid, antara yang menghantar memorandum tersebut ialah Raja-raja Melayu, Kerajaan Persekutuan, Parti Perikatan, Persatuan Erusian, Pertubuhan Tamil Malaya, Pertubuhan Cina Negeri Selat British, rakyat British di Melaka, Dewan Perniagaan Cina Malaya, Dewan Perniagaan Melayu Persekutuan Tanah Melayu, Dewan Perniagaan Pulau Pinang, Parti Buruh Malaya, Haji Baharudin bin Samsudin (N. Sembilan), R. Mallai (Perak), Persatuan Islam Malaya, cawangan Johor, Pertubuhan Guru-guru Sekolah Cina, Henry T. Wong (Kuala Lumpur), Pertubuhan India Kelahiran Malaya, Persatuan Cina Melaka, Dato' Naning, Haji Mohd Tahir (N.Sembilan), R.n. Veerappan dan lain-lain (Lihat lbid., hlm. 107). Lihat kandungan memorandum tersebut dalam CO 889/6, Federation of Malaya Constitutional Commission 1956, Memoranda Submitted by Individuals and Various Organisations.

19 Ismail Said, Dr.Burhanuddin al-Helmi: Pejuang Melayu Sejati, hlm. 49.

20 Joseph M. Fernando, The Making of the Malayan Constitution, hlm. 81.

21 Ibid., hlm. 147.

22 Utusan Melayu, 18 Mac 1957.

23 Lihat Laporan Ulasan PAS Terhadap Penyata Perlembagaan Reid yang dibentang dan dibahaskan dalam Sidang Mesyuarat Agung Khas PAS pada 2 Mei 1957 di Kuala Lumpur, Arkib Negara Malaysia.

24 Ibid.

25 lbid.

26 Ibid.

$27 \quad$ Ibid., hIm. 73.

28 Joseph M. Fernando, The Making of the Malayan Constitutional, hlm. 127.

29 Lihat Memorandum to the Reid Constitutional Commission, 27 September $1956 \mathrm{dlm}$. Fail UMNO/SUA No. 108/1956, Arkib Negara Malaysia.

30 Ibrahim Mahmood, Sejarah Perjuangan Bangsa, Kuala Lumpur: Penerbit Pustaka Antara, 1981, hlm. 564.

31 Persatuan Islam Sa-Malaysia (PAS), "Ulasan Terhadap Penyata Perlembagaan "Suruhanjaya Reid", Sidang Menyuarat Agong Khas Persatuan Islam Sa-Malaysia, 2 Mei 1957, Kuala Lumpur, Arkib Negara Malaysia, hlm, 8-9.

32. Perenggan 165, Laporan Reid menyebutkan; "We found little opposition in any quarter to the continuance of the present system for a time, but there was great opposition in some quarters to any increase of the present preferences and to their being continued for any prolonged periode. We are of opinion that in present circumstance it is necessary to contimue these preferences... Our reconmendations are made on the footing that the Malays should be assured that the present position will continue for a substantial period, but that in due course the present preferences should be reduce and should ultimately cease so 
there should then be no discrimination between races or communities. Lihat Federation of Malaya Constitutional Commission, 1956-1957, hlm. 72.

33 Perenggan 166, Laporan Reid menyebutkan; "With regard to laud we recommend (Art.82) that, subject to two qualifications, there should be no further Malay reservations, but that each State should be left to reduce Maloy rese riations in that Stale at an appropriate time..." .Ibid.

34 Perenggan 167, Laporan Reid menyebutkan; "...We recomniend that after 15 years there should be a review of the whole matter and the procedure should be that the appropriate Government should cause a report to be made and laid before the appropriate legislature; and that legislature should then determine either to retain or to reduce any quota or to discontinue it entirely. Ibid.

35 Persatuan Islam Sa-Malaysia (PAS), "Ulasan Terhadap Penyata Perlembagaan "Suruhanjaya Reid", Sidang Menyuarat Agong Khas Persatuan Islam Sa-Malaysia, 2 Mei 1957, Kuala Lumpur, Arkib Negara Malaysia, hlm. 10.

36 lbid., hlm. 11.

3. Laporan Reid menyebutkan "Islam as a State Religion" seperti yang dicadangkan oleh Parti Perikatan. Di dalam bahagian Apendix Laporan tersebut dinyatakan "Islam shall be the religion of the state of Malaya..." Lihat Federation of Malaya Constitutional Conmission, 1956-1957, hlm. 100. PAS dalam laporannya yang mengandungi kritikan terhadap Laporan Suruhanjaya Reid telah menggunakan istilah "Islam sebagai agama rasmi" bukannya "Islam sebagai agama bagi Persekutuan.

3s Ulasan PAS Terhadap Penyata Perlembagaan Suruhanjaya Reid yang dikeluarkan pada 2 Mei 1957

39 lbid.

4) lbid.

41 Menurut Fernando dari 22 Febuari hingga 27 April 195 , perbincangan telah diadakan sebanyak $23 \mathrm{kali}$. Lihat Joseph M. Fernando, The Making of the Malayan Constitution, hlm. 149. Wakil Perikatan ialah Tunku Abdul Rahman (Ketua Menteri Persekutuan/UMNO), Datuk Abdul Razak (UMNO), Ong Yoke Lin (MCA), V.T. Sambanthan (MIC), wakil dari Rajaraja ialah Tuan Haji Mustapha Albakri bin Haji Hassan, Shamsudin Nain, Tunku Ismail bin Tunku Yahya dan Neil Lawson. Turut menganggotai Working Party ialah Sir David Watherson (Ketua Setiausaha Kerajaan), T.V.A. Brodie (Peguam Negara) dan E.O. Laird (sebagai Setiausaha Working Party). lbid., hlm. 149.

42 Ibid.

4 lbid.

44 lbid., hIm. 165.

45 CO 1030/496, Federation of Malaya Constitutional Talks, Summary Record of the Fourth Plenary Meeting held in Church House on Tuesday $21^{\text {st }}$ May 1957.

4s CO 1030/494 (109), Federation of Malaya-Constitutional Talks, 20 June 1957.

47 Tunku Abdul Rahman, Malaysia The Road to Independence, Subang Jaya: Pelanduk Publications (M) Sdn. Bhd., hlm. 177. 
48 R.K. Vasil, Ethnic Politics in Malaysia, New Delhi: Radiant Publishers, 1980 , hlm. 33-34.

49 K.J. Ratnam, Communalism and the Political Process, Kuala Lumpur: University of Malaya Press, 1965, hlm. 61.

so Utusan Melayu, 1 Julai 1957.

51 Kebimbangan PAS bahawa Pulau Pinang dan Melaka masih menjadi hak baginda Queen ada kaitannya dengan perjuangan $P A S$ sebelum merdeka yang mengesyorkan supaya Negeri-negeri Selat iaitu Melaka dan Pulau Pinang menjadi sebahagian daripada negeri-negeri Melayu. Dengan cara tersebut, kedudukan istimewa orang Melayu akan dapat diperluaskan ke negeri-negeri ini dan dilindungi. (Lihat G.P. Means, Malaysian Politics, London: Hodder and Stoughton, 1976, hlm. 228). Bagaimanapun dalam Laporan Suruhanjaya Reid, kedudukan Negeri-negeri Selat telah dijelaskan seperti berikut, iaitu "Constitution of Penang and Melacca have been drafted on the footing that these Settlements will cease to be parts of Her Majesty's dominions and become autonomus States within the Federation on Merdeka Day" (Lihat Federation of Malaya Constitutional Conmission, 1956-1957, Kuala Lumpur: Government Printers, 1957, hlm. 95). Di samping itu, draf Akta Kemerdekaan Tanah Melayu yang akan dibentangkan di Parlimen British pada bulan Julai 1957ada menyebutkan bahawa perjanjian yang dibuat antara baginda Queen dengan Sembilan Raja-raja Melayu akan memasukkan (a) "procide for the formation of the nine States with the Settlements of Penang and Malacca into a newo independent Federation under a Constitution specified in the Agreement and for the application to those Settlements, as State of the new Federation, of the State Constitutions which would also be specified in the Agreenent" dan (b) provide for the termination of the Queen's sovereignty and jurisdiction in respect of the Settlements and Her poroer ang jurisdiction in the Malay States and Federation as a wolole" Lihat CO 1030/494, Constitution Talks On Malaya in London. May 1957.

52 Suara Islam, Bil. 9, Tahun 1, Ogos 1957, hlm.8.

53. Suara Islam, Bil. 10, Tahun 1, September 1957, hlm. 9.

54 Pengasul, Februari 1956, hlm. 1.

55 Qalam, November 1958, hIm. 3.

56 Lihat Perlembagaan PAS, Kuala Lumpur: Pejabat Agung Parti Islam Malaysia, 1977, hlm. 2.

57 Stara Islam, bil. 11, tahun 1, Oktober 1957, hIm. 4.

58 Suara Islam, bil. 10, tahun 1, September 1957, hlm. 9-10.

59 Suara Islam, bil. 9, tahun 1, Ogos 1957, hlm. 17.

bo Suara Islam, bil. 8, tahun 2, Julai 1958, hlm. 16.

61 Lihat "Islam pragmatik, umat Islam mesti waspada", dlm. Suara lslam Ke aralt Menegak Daulah Islamiah, Bil. 6, Safar 1401H/Dis. 1980. Matlamat perjuangan PAS bukan sekadar untuk membela bangsa dan negara seperti yang diperjuangkan oleh parti politik lain, tetapi bertujuan menegakkan Islam dan hukum Allah yang memberi jaminan kepada semua tanpa mengira keturunan dan bangsa. PAS melihat politik adalah sebahagian daripada agama dan politik tidak mungkin dipisahkan dari agama. 
Melaksanakan hukum Allah dalam aspek undang-undang, ekonomi, politik, sosial dan sebagainya tidak mudah dilaksanakan melainkan dengan diwujudkan sebuah pemerintahan Islam. Kuasa adalah syarat utama untuk melaksanakan hukum Allah. Dengan sebab itu, PAS berjuang untuk mendapatkan kuasa politik bagi wasilah untuk melaksanakan hukum Allah. (Lihat Memahani dan Mengenali Periuangan PAS, Kuala Lumpur: Jabatan Penerangan PAS Pusat, t.t., h/m. 6-7).

62 Lihat Federal Legislative Council Debates, 1 May 1958, hIm. 4671-4672

6.3 Parliamentary Debates, First Parliament Derwan Rakayat, Volume 1 Ist Session, September 1959-February 1960, hlm. 1550.

64 Berita Harian, 20 November 1968.

6.5 The Straits Times, 9 Mac 1959.

on Berita Harian, 7 Disember 1968.

G7 Qalam, bil.105, April 1959, hlm. 5.

6. Dalam mesyuarat agung PAS yang diadakan di Kuala Lumpur pada 24 dan 25 Ogos 1957, PAS telah berazam dan berikrar akan:

i). Bahawa Persatuan Islam SaMalaya tetap terus memperjuangkan hasrat kebangsaan Melayu menurut anggaran dasar perjuangan PAS.

ii). Bahawa dalam persidangan agung PAS 1956 dahulu telah menetapkan agar kemerdekaan negeri ini tidak boleh diganjak daripada tarikh 31 Ogos 1957; maka dalam persidangan ini setelah mempelajari dan meneliti nyatalah bahawa nilai merdeka 31 Ogos ini masih kosong daripada cita-cita perjuangan PAS. Maka persid angan ini dengan sebulatnya berazam dan berikrar akan berjuang terus bagi mengisi kemerdekaan yang isytiharkan pada 31 Ogos ini dengan hasrat kebangsaan Melayu yang penuh bagi menegakkan keadilan masyarakat, keamanan dan kemakmuran rakyat negeri ini. Sesuai dengan cita-cita Islam yang diperjuangkan oleh PAS.

iii). Bahawa cita-cita IsIam yang diperjuangkan oleh PAS ialah mengambil tempat yang sesuai dengan ayat "ummaton aassatan" dengan menjalankan perintah "menyeru ke arah kebaikan dan mencegah kemungkaran" hingga berdirilah sebuah Negara Islam "buldatan tayyaibah wa rabun ghafur" di tanah air kita ini (Lihat Suara Islam, bil. 10, tahun 1, September1957, hlm. 4. Menurut Da Abdul Jalil bin Hj. Awang (wakil dari Terengganu), walaupun PAS memperjuangkan Melayu sebagai kebangsaan, namun ini tidak bererti PAS akan menyingkirkan hak kaum lain atau menzalimi hak orang bukan Melayu, tetapi yang ingin ditegaskan dan dikawal oleh orang Melayu ialah hak politik dan kaum Melayulah menjadi tuan punya negeri ini. Akibat hak kerakyatan yang diberi terlampau longgar, keadaan ini amat membimbangi orang Melayu bahawa hak mereka akan terhapus di tanah airnya sendiri. Lihat Perbaluasan Parlinen Deroan Negara, Parlimen Pertama Penggal Kelima, Jilid V 1963-1964, hlm. 268-269.

6. Ramlah Adam, Dato' Onn Ja'afar, cet. 5, Kuala Lumpur: Dewan Bahasa dan Pustaka, 2005, hlm. 380. 
70 Ismail Said, Dr.Burhanuddin al-Helmi, hlm. 97.

7 Parliamentary Debates, Devan Ra'ayat Official Report, Second Session of the Second Parliament of Malayasia, Vol. Il, No. 1, 26 May 1965, hIm. 161.

72 K.J. Ratnam and R.S. Milne, The Malayan Parliamentary Election, of 1964, Singapore: University of Malaya Press, 1967, hlm. 120-121.

73 Mohamad Bakar, "Konservatisme dan Konflik: Isu Kafir Mengkafir dalam Politik Kepartian Melayu", Persidangan Antarabangsa Pengajian Melayu, 21-23 Ogos 1989, Jabatan Pengajian Melayu, Universiti Malaya.

$74 \quad$ K.J. Ratnam and R.S. Milne, The Malayan Parliamentary Election, hlm. 120121.

75 Ibid., hlm. 121.

76 Lihat "Tugas Kita Terhadap Negara", dlm. Gerakan "Tahan Lasak" Pergerakan Pemuda UMNO Malaysia, t.t., hlm. 23-24.

77 "Islam Pragmatik, Umat Islam Mesti Waspada", dlm. Suara Islam Ke arah Menegak Daulah Islamiah, Bil. 6, Safar 1401/Dis. 1980.

78 Parliamentary Debates, Deroan Ra'ayat Official Report, Third Session of the Second Parliantent of Malaysia, Vol. III, No. 46, $3^{\text {rd }}$ March 1967, hlm. 6195.

79 Warta Malaysia, 23 Januari 1969.

80) Lihat Penyata UMNO 1967, hlm. 33-34.

s1 Lihat "Masjid Usang Kawasan PAS", Berita Harian, 19 Disember 1968.

82 Gerakan Pemuda Tahan Lasak telah ditubuhkan oleh Senu Abdul Rahman ketika beliau menjadi Ketua Pemuda UMNO untuk Penggal 1964/1965. Lihat Zin Mahmud et al. Kepimpinan E Perjuangan Pemuda UMNO, hlm. $42-43$.

83. Lihat "Tugas Kita Terhadap Negara", dlm. Gerakan "Tahan Lasak" Pergerakan Penuda UMNO Malaysia, t.t., hlm. 23.

84 Ibid.

85 Lihat Paridah Ali, "Sejarah PAS di Kelantan 1953-1959", JEBAT, Bil. 3/4, 1973/9/1974/5, hlm. 84-86, lihat juga Ismail Said, Dr. Buhanuddin al Helmy, hIm. 80-83.

86 Straits Budget, 5 Ogos 1959.

s7 Berita Harian, 1 Julai 1959.

s8 Tunku Abdul Rahman, 13 Mei, hlm. 22.

89 The Straits Times, 6 Mac 1959. Tuduhan ini sama dengan kebimbangan British terhadap potensi PKM menggunakan agama Islam bagi meningkatkan sokongan orang Melayu terhadap perjuangan mereka. Menurut sebuah Laporan sulit yang dikeluarkan oleh Special Branch, Polis Persekutuan Tanah Melayu mencatatkan "The MCP viezos the exploitation of the Islanic religion as its most powerful weapon for obtaining increased support from the Malay community. Thus MCP propaganda towards the Malay follows almost identically the dual themes produced by such Pan-Islantic organizations as the World Muslim Brotherhood namely: a) that Malay should not be ruled by infidel imperialist Government; b) that the depressed Muslim peoples should struggle for improved economic and education standards. The MCP Malay Department of Work, which has been created specifically for the task of draning the Malay community in to the anti-Britisl and anti-colonial united front, is currently producing well thought-out propaganda on these lines and has been given, among 
its priority targets for penetration, Malay Religious teachers Malay youth, and Malay religious schools. Lihat CO 1035/20, The Pan-Islamic Movement in Malaya, 1954-1956.

90) The Straits Times, 10 Mac 1959. Pemimpin UMNO dalam pilihan raya 1969 mengulangi dakwaan yang sama bahawa. PAS berkerjasama dengan Komunis. Dakwaan ini telah dibuat oleh Senu Abdul rahman (Menteri Penerangan) ketika berucap di Kelantan pada pertengahan bulan April 1969. Menurutnya, beliau telah menerima laporan bahawa Komunis telah menyeberang sempadan Malaysia-Thailand dan menyusup masuk ke dalam kampong di Batu Melintang dan Batu Gajah menyeru orang ramai menyokong PAS. Lihat R.K. Vasil, The Malaysian General Election, h.m. 27.

Gerita Harian, 21 Julai 1959.

on Lihat Ahmad Zaki Hj. Abd Latiff, "Pengaruh Gerakan Islam Timur Tengah Dalam Perkembangan Pemikiran Agama dan Politik Masyarakat Melayu (1971-1998)", Tesis Doktor Falsafah, Jabatan Sejarah, Universiti Malaya, 2008 , hlm. 164.

93 Lihat 1998/0018115, Memorandum Daripada Majlis Kebangsaan Bagi Hal Ehwal Ugama Islam, "Kafir Mengkafir Sesama Islam", Jawatankuasa Fatwa Majlis Kebangsaan Bagi Hal Ehwal Ugama Islam, Malaysia, 3 Disember 1984, Arkib Negara Malaysia.

94 Utusan Melayu, 5 November 1963.

95 Ibid.

96. Lihat 1998/0003417, Siaran Jawatankuasa Tetap Agama Bagi Majlis RajaRaja Berkenaan Kufur Mengkufurkan Seseorang Yang selalu Terjadi Dalam Kempen Parti-Parti Siasah Atau Lainnya, 4 Julai 1963, Arkib Negara Malaysia.

47. Lihat 2002/0006773, PAS Anggap Sepi Amaran Tunku, Arkib Negara Malaysia.

98 Ibid. 